\title{
ANALISIS SISTEM PROTEKSI OVERCURRENT RELAY PEMBANGKIT LISTRIK TENAGA UAP PT. MAKASSAR TENE
}

\author{
A. Anugrah Shafar ${ }^{1)}$, Ahmad Gaffar ${ }^{2)}$ \\ ${ }^{1), 2), 3)}$ Teknik Elektro, Politeknik Negeri Ujung Pandang \\ Email:anugrah2805@gmail.com ${ }^{1)}$,ahmadgaffar@gmail.com ${ }^{2)}$
}

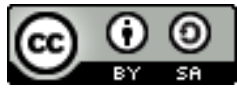

\begin{abstract}
Abstrak
Analisis sistem proteksi overcuurent relay merupakan penelitian yang dilakukan untuk mengetahui besar nilai arus hubung singkat 3 phasa yang terjadi di setiap bus atau titik. Dengan mengetahui nilai arus hubung singkat 3 phasa, penulis dapat menentukan setting yang tepat pada overcurrent relay dalam menangani gangguan hubung singkat yang terjadi serta alur koordinasi yang dilakukan oleh setiap relay. Dalam penelitian yang dilakukan di PT. Makassar Tene ini, titik yang diteliti sebagai gangguan yaitu berada pada bus 1, bus 3 dan bus 7. Perhitungan hubung singkat 3 phasa dilakukan dengan metode perhitungan manual dengan menggunakan matriks impedansi dan simulasi menggunakan Digsilent Powerfactory 15.1. Hasil perhitungan manual diperoleh arus pada bus 1 sebesar 2,06 kA, bus 3 sebesar 4,6 kA dan bus 7 sebesar 10,5 kA. Hasil simulasi Digsilent Powerfactory 15.1 diperoleh arus pada bus 1 sebesar 2,3 kA, bus 3 sebesar 4,9 kA dan bus 7 sebesar 9,6 kA. Berdarkan hasil besaran arus hubung singkat, maka setting pada OCR1 sebesar 53 A, OCR2 sebesar 30,82 A, OCR3 sebesar 809,24 A, OCR6 sebesar 44,04 A dan OCR7 sebesar 924,85 A.
\end{abstract}

Kata kunci: Overcurrent Relay, Arus, Hubung Singkat, Proteksi, Setting TMS.

\section{PENDAHULUAN}

Pemasangan sistem proteksi pada sebuah peralatan listrik yang kurang tepat dapat mengakibatkan seringnya terjadi kegagalan bekerja sehingga terjadi kerusakan pada peralatan listrik tersebut. Oleh karena itu perlu adanya penelitian terhadap sistem proteksi yang digunakan sebuah komponen listrik untuk memperbaiki kinerja dan meningkatkan produktivitas dari sebuah industri.

PLTU PT. Makassar Tene yang memiliki daya output $18 \mathrm{MW}$ yang terdiri dari 3 unit generator yang masing - masing mempunyai daya output $6 \mathrm{MW}$ yang didistribusikan melalui system tegangan menegah 10 kV. Dalam sistem proteksi generator, PT. Makassar Tene menggunakan beberapa relay yang bekerja untuk memproteksi bagian generator ketika mengalami kegagalan beroperasi. Namun pada kenyataanya, sistem proteksi yang bekerja pada generator PLTUPT. Makassar Tene beberapa kali mengalami kegagalan bekerja sehingga mengakibatkan beberapa komponen lain mengalami kerusakan atau berhenti beroperasi. Hal ini tentunya berdampak pada efektivitas mesinmesin produksi dalam industri tersebut.

Untuk mengatasi permasalahan tersebut perlu adanya pengaturan pada sistem proteksi tersebut yang tepat dengan cara mengetahui gangguan yang terjadi. Gangguan hampir selalu ditimbulkan oleh hubung singkat antar fase atau hubung singkat fase ke tanah. Suatu gangguan hampir selalu berupa hubung langsung atau melalui impedansi. Istilah gangguan identik dengan hubung singkat, sesuai standart ANSI/IEEE Std. 100-1992.

Hubung singkat merupakan suatu hubungan abnormal (termasuk busur api) pada impedansi yang relatif rendah terjadi secara kebetulan atau disengaja antara dua titik yang mempunyai potensial yang berbeda. Istilah gangguan atau gangguan hubung singkat digunakan untuk menjelaskan suatu hubungan singkat. Untuk mengatasi gangguan tersebut, perlu dilakukan analisis hubung singkat sehingga sistem proteksi yang tepat pada Sistem Tenaga Listrik dapat ditentukan.

Analisa gangguan hubung singkat adalah analisis yang mempelajari kontribusi arus gangguan hubung singkat yang mungkin mengalir pada setiap cabang di dalam sistem sewaktu gangguan hubung singkat yang mungkin terjadi di dalam sistem tenaga listrik. Analisis gangguan hubung singkat merupakan suatu hal yang penting untuk menentukan rating arus hubung singkat, guna untuk melindungi perangkat dan peralatan sistem distribusi dari efek yang ditimbulkan beban (Mathur, 2015).

Maka dengan menghitung nilai arus hubung singkat, penulis dapat memperoleh nilai setting arus proteksi yang diharapkan dapat berfungsi untuk melakukan perlindungan ketika terjadi gangguan hubung singkat 3 phasa. 


\section{KAJIAN LITERATUR}

A. Generator

Sistem pembangkitan listrik yang sudah umum digunakan adalah mesin generator tegangan AC,

di mana penggerak utamanya bisa berjenis mesin turbin, mesin diesel atau mesin baling-baling. Dalam pengoperasian pembangkit listrik dengan generator, karena faktor keandalan dan fluktuasi jumlah beban, maka disediakan dua atau lebih generator yang dioperasikan dengan tugas terus-menerus, cadangan dan bergiliran untuk generator-generator tersebut. Penyediaan generator tunggal untuk pengoperasian terus menerus adalah suatu hal yang riskan, kecuali bila bergilir dengan sumber PLN atau peralatan UPS.

Menurut William dan Jr, Stevenson (1996:122) kontruksi generator sinkron merupakan susunan ferromagnetik yang terdiri dari tiga bagian utama, yaitu :

a Bagian yang diam, yang pada dasarnya adalah sebuah silinder kosong di namakan stator, dan mempunyai parit-parit (slots) memanjang yang di dalamnya terdapat lilitan kumparan stator

b. Bagian dari mesin yang dipasang pada poros dan berputar di dalam stator yang kosong disebut rotor, lilitan pada rotor dinamakan lilitan medan dan dicatu dengan arus dc

c. Celah udara adalah ruangan antara stator dan rotor, dapat dilihat pada gambar 1 tampak dalam generator.

B. Gangguan Hubung Singkat

Gangguan hubungan singkat yang mungkin

terjadi dalam jaringan (Sistem kelistrikan) yaitu :

1. Gangguan hubungan singkat tiga fasa

2. Gangguan hubungan singkat dua fasa

3. Gangguan hubungan singkat satu fasa ke tanah

Semua gangguan hubungan singkat diatas,

arus gangguannya dihitung dengan menggunakan rumus dasar yaitu :

$I=$

$\frac{V}{Z}$

Dimana

$\mathrm{I}=$ Arus yang mengalir pada hambatan $\mathrm{Z}(\mathrm{A})$

$\mathrm{V}=$ Tegangan sumber $(\mathrm{V})$

$\mathrm{Z}=$ Impedansi jaringan $(\Omega)$

Yang membedakan antara gangguan hubungan singkat tiga fasa, dua fasa dan satu fasa ke tanah adalah impedansi yang terbentuk sesuai dengan macam gangguan itu sendiri, dan tegangan yang memasok arus ke titik gangguan. Impedansi yang tebentuk dapat ditunjukan seperti berikut ini :

$\mathrm{Z}$ untuk gangguan tiga fasa, $\mathrm{Z}=\mathrm{Z}_{1}$

$\mathrm{Z}$ untuk gangguan dua fasa, $\mathrm{Z}=\mathrm{Z}_{1}+\mathrm{Z}_{2}$

$\mathrm{Z}$ untuk gangguan satu fasa, $\mathrm{Z}=\mathrm{Z}_{1}+\mathrm{Z}_{2}$

$\mathrm{Z}_{0}$

Dimana:

$\mathrm{Z}_{1}=$ Impedansi urutan positif $(\Omega)$
$\mathrm{Z}_{2}=$ Impedansi urutan negatif $(\Omega)$

$\mathrm{Z}_{0}=$ Impedansi urutan nol $(\Omega)$

Sebelum melakukan perhitungan arus hubung singkat, maka kita harus memulai perhitungan pada rel daya tegangan primer di gardu induk untuk berbagai jenis gangguan, kemudian menghitung pada titik - titik lainnya yang letaknya semakin jauh dari gardu induk tersebut. Untuk itu diperlukan pengetahuan mengenai dasar impedansi urutan rel daya tegangan tinggi atau bisa juga disebut sebagai impedansi sumber, impedansi transformator, dan impedansi penyulang.

Perhatikan gambar 1 mengenai pembagian impedansi sumber dan transformator.

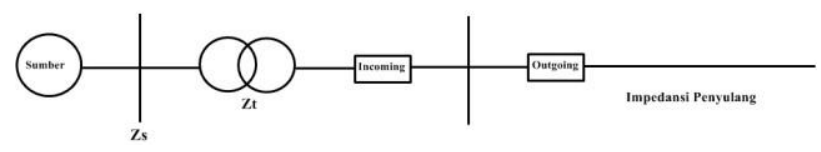

Gambar 1 Sketsa penyulang tegangan menengah Dimana :

$\mathrm{X}_{\mathrm{S}}=$ Impedansi sumber $(\Omega)$

$\mathrm{X}_{\mathrm{T}}=$ Impedansi Transformator $(\Omega)$

C. Impedansi Sumber

Untuk menghitung impedansi sumber di sisi bus $20 \mathrm{kV}$, maka harus dihitung dulu impedansi sumber di bus $150 \mathrm{kV}$. Impedansi sumber di bus $150 \mathrm{kV}$ diperoleh dengan rumus :

$\mathrm{Xs}=\frac{\mathrm{kV}^{2}}{\mathrm{MVA}}$

Dimana:

Xs $\quad=$ Impedansi sumber $(\Omega)$

$\mathrm{kV}^{2} \quad=$ Tegangan sisi primer trafo tenaga

MVA = Daya hubung singkat di bus $150 \mathrm{kV}$

D. Impedansi Transformator

Pada perhitungan impedansi suatu transformator yang diambil adalah harga reaktansinya, sedangkan tahanannya diabaikan karena harganya kecil. Untuk mencari nilai reaktansi trafo dalam Ohm dihitung dengan cara sebagai berikut.

Langkah petama mencari nilai ohm pada $100 \%$ untuk trafo pada $20 \mathrm{kV}$, yaitu dengan menggunakan rumus

$\mathrm{Xt}($ pada $100 \%) \frac{\mathrm{kV}^{2}}{\mathrm{MVA}}$.

(4)

Dimana :

$\mathrm{Xt} \quad=$ Impedansi trafo tenaga $(\Omega)$

$\mathrm{kV}^{2} \quad=$ Tegangan sisi primer trafo tenaga

MVA = Kapasitas daya trafo tenaga

E. Impedansi Penyulang

Untuk perhitungan impedansi penyulang, perhitungannya tergantung dari besarnya impedansi per $\mathrm{km}$ dari penyulang yang akan dihitung, dimana besar nilainya tergantung pada jenis penghantarnya, yaitu dari bahan apa penghantar tersebut dibuat dan 
juga tergantung dari besar kecilnya penampang dan panjang penghantarnya. Disamping itu penghantar juga dipengaruhi perubahan temperatur dan konfigurasi dari penyulang juga sangat mempengaruhi besarnya impedansi penyulang tersebut.

Contoh besarnya nilai impedansi suatu penyulang yaitu $Z=(R+j X)$. Sehingga untuk impedansi penyulang dapat ditentukan dengan menggunakan rumus :

a. Urutan positif dan urutan negatif

$\mathrm{Z} 1=\mathrm{Z} 2$ = panjang penyulang $(\mathrm{km}) \times \mathrm{Z} 1 / \mathrm{Z} 2$

$(\Omega)$

Dimana :

$\mathrm{Z1}=$ Impedansi urutan positif $(\Omega)$

$\mathrm{Z} 2$ = Impedansi urutan negatif $(\Omega)$

b. Urutan nol

$\mathrm{Zo}=$ panjang penyulang $(\mathrm{km}) \quad \mathrm{x} \quad \mathrm{Zo}$

$(\Omega)$

Dimana :

$\mathrm{Zo}=$ Impedansi urutan nol $(\Omega)$

\section{F. Impedansi Ekivalen}

Menghitung besar impedansi ekivalen adalah akumulasi dari besar nilai impedansi positif dan negatif dari titik gangguan sampai ke sumber. Karena dari sumber ke titik gangguan impedansi yang terbentuk adalah terhubung seri maka perhitungan impedansi ekivalen positif dan negatif dapat dijumlah langsung. Adapun untuk menghitung impedansi ekivalen jaringan dapat dihitung dengan menggunakan persamaan :

a Urutan Positif dan Urutan Negatif $\left(Z_{1 \text { eq }}=Z_{2 e q}\right)$

$\mathrm{Z}_{1 \text { eq }}=\mathrm{Z}_{2 \mathrm{eq}}=\mathrm{Z}_{\mathrm{s} 1}+\mathrm{Z}_{\mathrm{T} 1}+\mathrm{Z}_{1}$ penyulang... (7)

Dimana :

$\mathrm{Z}_{1 \text { eq }}$ : Impedansi equivalen urutan positif $(\Omega) \mathrm{Z}_{2 \mathrm{eq}}$

: Impedansi equivalen urutan negatif $(\Omega) \mathrm{Z}_{\mathrm{s} 1}$ :

Impedansi sumber sisi $20 \mathrm{kV}(\Omega)$

$\mathrm{Z}_{\mathrm{T} 1}$ : Impedansi trafo urutan positif dan negatif

$(\Omega)$

$\mathrm{Z}_{1} \quad$ : Impedansi penyulang positif $(\Omega)$

b. Urutan nol

$\mathrm{Z}_{0 \text { eq }}=\mathrm{Z}_{\mathrm{t} 0}+3 \mathrm{RN}+\mathrm{Z}_{0}$ penyulang

Dimana :

$\mathrm{Z}_{0 \text { eq }} \quad$ : Impedansi ekivalen jaringan nol $(\Omega)$

$\mathrm{Z}_{\mathrm{t} 0} \quad$ : Impedansi trafo tenaga urutan nol $(\Omega)$

RN : Tahanan tanah trafo tenaga $(\Omega)$

$\mathrm{Z}_{0} \quad$ : Impedansi urutan $\operatorname{nol}(\Omega)$

G. Relay Proteksi

Relay proteksi adalah susunan peralatan yang direncanakan untuk dapat merasakan atau mengukur adanya gangguan atau mulai merasakan tenaga listrik dan segera otomatis memberi perintah untuk membuka pemutus tenaga untuk memisahkan peralatan atau bagian dari sistem proteksi yang terganggu dan memberikan isyarat berupa lampu atau bel. Relay proteksi dapat merasakan adanya gangguan pada peralatan yang diamankan dengan mengukur atau membandingkan besaran-besaran yang diterimanya, misalnya arus, tegangan, daya, sudut fase, frekuensi, impedansi dan sebagainya, dengan besaran yang telah ditentukan kemudian mengambilnya keputusan untuk seketika ataupun dengan perlambatan waktu membuka pemutus tenaga.

Dari fungsinya diatas, adakalanya ada kegagalan dalam pengaman relay proteksi. Hal-hal yang dapat menimbulkan kegagalan pengaman dapat di kelompokan sebagai berikut :

1. Kegagalan pada relay itu sendiri

2. Kegagalan suplai arus dan/atau tegangan ke relay tegangannya rangkaian suplai ke relay dari trafo tersebut terbuka atau terhubung singkat.

3. Kegagalan sistem suplai arus searah untuk triping pemutus tenaga. Hala yang dapat menyebabkan nya antara lain baterai lemah karena kurang perawatan, terbukanya atau terhubung singkat rangkaian arus searah.

4. Kegagalan pemutus tenaga. Kegagalan in dapat disebabkan karena kumparan trip tidak menerima suplai, kerusakan mekanis ataupun kegagalan pemutusan arus kemampuan dari pemutus tenaganya.

Karena ada kemungkinan kegagalan pada sistem pengaman maka arus dapat diatasi yaitu dengan penggunaan pengaman cadangan (Back $U p$ Protection). Dengan demikian pengaman menurut fungsinya dapat dikelompokan menjadi :

1. Pengaman utama yang pada umumnya selektif dan cepat dan malah jenis tertentu mempunyai sifat selektif mutlak misalnya relay diferensial.

2. Pengaman cadangan, umumnya mempunyai perlambatan waktu hal ini untuk memberikan kesempatan kepada pengaman utama bekerja terlebih dahulu, dan jika pengaman utama gagal, baru pengaman cadangan bekerja dan relay ini tidak seselektif pengaman utama.

\section{METODE PENELITIAN}

A. Teknik pengumpulan Data

Teknik pengumpulan data yang dilakukan pada penelitian ini adalah sebagai berikut :

1. Survei adalah melakukan kunjungan atau pengamatan langsung di PT. Makassar Tene, untuk mengetahui kondisi riil dan mendapatkan data-data yang diperlukan dan informasi penting lainnya dalam penyusunan tugas akhir ini.

2. Wawancara data ini dilakukan dengan mengadakan tatap muka atau wawancara secara langsung dengan pimpinan perusahaan atau orang-orang yang 
mempunyai pengetahuan yang ada kaitannya dengan penyusunan tugas akhir ini.

3. Studi Literatur adalah suatu kegiatan yang dilakukan dengan mengadakan studi dari bukubuku/pustaka, situs-situs internet dan literatur lain yang berkaitan dengan masalah yang dibahas dalam penulisan ini.

\section{B. Teknik Analisa Data}

Teknik analisa data akan dilakukan dengan 2 cara yaitu menghitung nilai arus hubung singkat dan simulasi pada aplikasi DIGSILENT POWER FACTOR 15.2. Dengan membandingkan hasil analisa dan simulasi pada aplikasi maka akan diketahui setting relay yang diperlukan pada sistem proteksi.

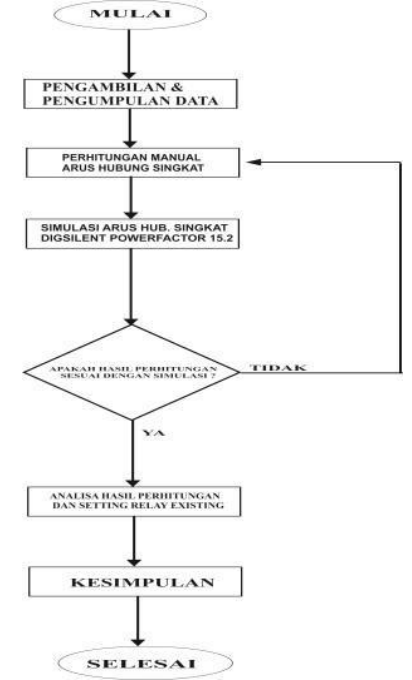

Gambar 2 Flowchart Penelitian

\section{HASIL DAN PEMBAHASAN}

A. Hasil

Pendistribusian listrik PT. Makassar Tene diatur dengan mengacuh pada single line diagram. Distribusi listrik Makassar tene disalurkan ke lima feeder utama. Feeder - feeder tersebut antara lain :

1. Supply to $\mathrm{CO}_{2}$ station

2. Supply to PLN (not operated)

3. Supply to Circulating Pump

4. Supply to Distribution Panel
a. Sub station \#1 Transformator 1
b. Sub station \#1 Transformator 2
c. Sub station \#2 Transformator 1
d. Sub station \#2 Transformator 2
e. Transformator Spray Pond

5. Supply to internal feeder.
a. Trafo Power Plant \# 0
b. Trafo Power Plant \# 1
c. Trafo Power Plant \# 2

A.1. Data Generator

Spesifikasi generator yang digunakan di PT. Makassar Tene adalah :

- Pabrik : Shandong Jinan Power Equipment Factory
- Model : QF -6-2

- Rated output : $7500 \mathrm{KVA}$

- Rated power : $6000 \mathrm{KW}$

- Rated voltage : $10500 \mathrm{~V}$

- Rated current : 412 A

- Rated speed : $3000 \mathrm{rpm}$

- Rated Frequency : $50 \mathrm{~Hz}$

- Exciting current : $233.4 \mathrm{~A}$

- Power factor : 0.8 Lagging

- Connection Style : Y

A.2. Data Transformator Spesifikasi transformator yang digunakan di

PT. Makassar Tene adalah :

- Transformer \#0 : 2000kVA, 10,5kV/0,4kV, DYn5

- Transformer \#1 : 2000kVA, 10,5kV/0,4kV,DYn5

- Transformer \#2 : 2000kVA, 10,5kV/0,4kV,DYn5

- Trafo Subs 1 \#1 : 1600kVA, 10,5kV/0,4kV, DYn5

- Trafo Subs 1 \#2 : 1600kVA, 10,5kV/0,4kV, DYn5

- Trafo Subs 2 \#1 : 1600kVA, 10,5kV/0,4kV, DYn5

- Trafo Subs 2 \#2 : 1600kVA, 10,5kV/0,4kV, DYn5

- Trafo Pompa : $800 \mathrm{kVA}, 10,5 \mathrm{kV} / 0,4 \mathrm{kV}, \mathrm{DYn} 5$

- Trafo CO2 : 800kVA, 10,5kV/0,4kV, DYn5

- Trafo Sprayfond : 2000kVA, 10,5kV/0,4kV, DYn5

A.3. Data Transformator Spesifikasi transformator yang digunakan di

PT. Makassar Tene adalah :

- Transformer \#0 : 2000kVA, 10,5kV/0,4kV,DYn5

- Transformer \#1 : 2000kVA, 10,5kV/0,4kV,DYn5

- Transformer \#2 : 2000kVA, 10,5kV/0,4kV,DYn5

- Trafo Subs 1 \#1 : 1600kVA, 10,5kV/0,4kV, DYn5

- Trafo Subs 1 \#2 : 1600kVA, 10,5kV/0,4kV, DYn5

- Trafo Subs 2 \#1 : 1600kVA, 10,5kV/0,4kV, DYn5

- Trafo Subs 2 \#2 : 1600kVA, 10,5kV/0,4kV, DYn5

- Trafo Pompa : 800kVA, 10,5kV/0,4kV, DYn5

- Trafo CO2 : 800kVA, 10,5kV/0,4kV, DYn5 Trafo Sprayfond : 2000kVA, 10,5kV/0,4kV, DYn5 A.4. Data Penghantar

Spesifikasi penghantar yang digunakan di PT. Makassar Tene adalah :

- XLPE Type Hawk (10,5kV) : $240 \mathrm{~mm}^{2}, \mathrm{Z1}=0,1344$ $+\mathrm{j} 0,3158 \Omega / \mathrm{km}, \mathrm{Z} 0=0,2824+\mathrm{j} 1,6003 \Omega / \mathrm{km}, 100 \mathrm{~m}$

- XLPE Type Hawk $(0,4 \mathrm{kV}): 120 \mathrm{~mm}^{2}, \mathrm{Z1}=0,2688+$ $\mathrm{j} 0,3376 \Omega / \mathrm{km}, \mathrm{Z} 0=0,4618+\mathrm{j} 1,6251 \Omega / \mathrm{km}, 1100 \mathrm{~m}$

- XLPE Type Hawk $(0,4 \mathrm{kV}): 120 \mathrm{~mm}^{2}, \mathrm{Z} 1=0,2542+$ j0,07225 $\Omega / \mathrm{km}, Z 0=1,0167+\mathrm{j} 0,289 \Omega / \mathrm{km}, 1000 \mathrm{~m}$

- PVC Type Hawk $(0,4 \mathrm{kV}): 240 \mathrm{~mm}^{2}, \mathrm{Z1}=0,1267+$ $\mathrm{j} 0,07225 \Omega / \mathrm{km}, \mathrm{Z0}=0,5067+0,072256 \Omega / \mathrm{km}, 300$ $\mathrm{m}$

\section{A.4. Data Beban} Spesifikasi beban yang digunakan di PT.

Makassar Tene adalah :

- Beban 1: $460 \mathrm{~kW}, 400$ Volt, pf 0,8, xd” $20 \%$

- Beban 1 : $910 \mathrm{~kW}, 400$ Volt, pf 0,8, xd" $20 \%$ 


\section{A.5. Data Relay}

Spesifikasi overcurrent relay yang digunakan di PT. Makassar Tene adalah :

- Type 8602 : Standard Inverse, 1200/5, tms 0,1.

- Type 8000 : Standard Inverse, 50/5, tms 0,1.

- Type 8600 : Standard Inverse, 100/5, tms 0,1.

B. Pembahasan

B.1. Simulasi Aplikasi Hubung Singkat 3 Fasa Menggunakan aplikasi Digsilent PowerFactor 15.1. dengan menggambar SingleLine Diagram daerah Power Plant PT. Makassar Tene dan memasukkan datadata yang diperoleh pada data pengamatan. Hasil Single Line Dagram ditampilkan pada gambar 3

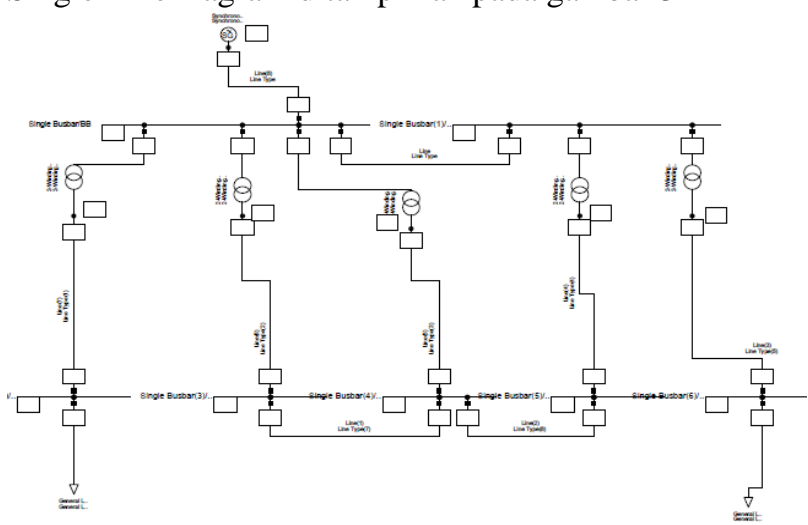

Gambar 3 SLD Power Plant PT. Makassar Tene

Setelah semua data dimasukkan, maka selanjutnya memilih bus yang akan ditinjau nilai arus saat terjadi hubung singkat 3 fasa. Pada hal ini penulis memilih menghitung arus hubung singkat pada bus $\mathrm{H}$ dengan melakukan pengaturan hubung singkat.

Setelah tombol eksekusi dipilih, maka data bus $\mathrm{H}$ ketika terjadi arus hubung singkat 3 fasa yang diperoleh melalui simulasi aplikasi Digsilent PowerFactor 15.1 ditampilkan pada gambar 5.

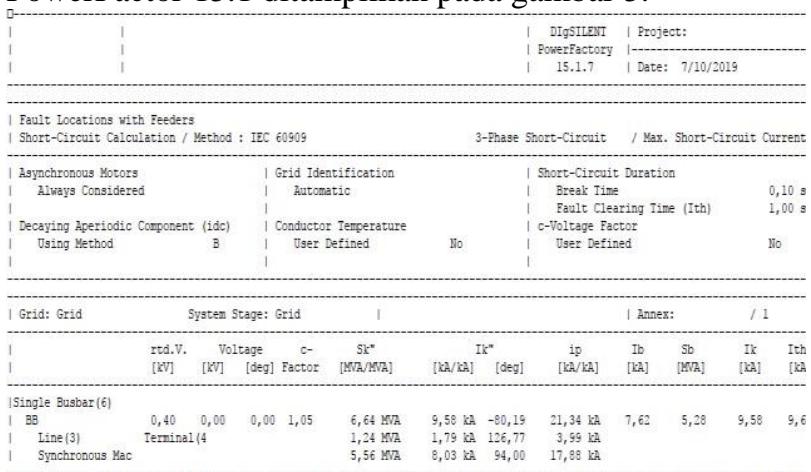

Gambar 5 Hasil Simulasi Hubung Singkat DigSilent PowerFactor 15.1

B.2. Analisis Perhitungan Hubung Singkat

Berdasarkan Single Line Diagram, maka dibuat diagram ekivalen untuk memudahkan menghitung nilai arus hubung singkat 3 fasa. Perhitungan hubung singkat 3 fasa menggunakan nilai impedansi urutan positif (Z1) pada setiap penghantar dan komponen listrik. Berikut diagram ekivalen yang telah dibuat ditampilkan pada gambar 6 .

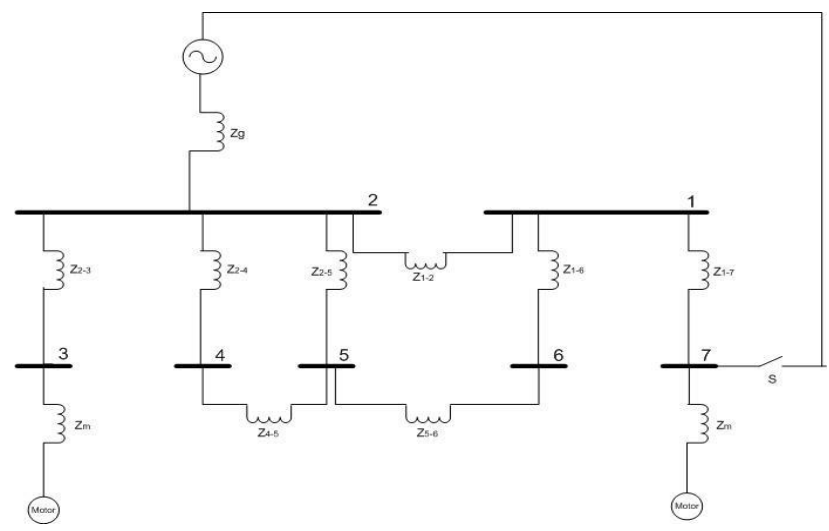

Gambar 6 Diagram Ekivalen PT. Makassar Tene

Dengan menggunakan data yang diperoleh pada pengamatan, maka dapat ditentukan nilai-nilai $\mathrm{Z}$ dengan cara :

$$
\begin{aligned}
& Z \text { baru per }- \text { unit }=0,2\left(\frac{10,5}{10,5}\right)^{2} *\left(\frac{7500}{7500}\right) \\
& Z \text { baru per }- \text { unit }=0,2 * 1^{2} * 1 \\
& Z \text { baru per }- \text { unit }=0,2 P . U
\end{aligned}
$$$$
\text { 2. Impedansi Motor } 1
$$$$
\mathrm{X}^{\prime}=20 \%
$$$$
Z \text { baru per }- \text { unit }=0,2\left(\frac{0,4}{10,5}\right)^{2} *\left(\frac{7500}{528,735}\right)
$$$$
Z \text { baru per }- \text { unit }=0,2 * 0,0381^{2} * 14,18
$$$$
Z \text { baru per }- \text { unit }=0,0042 \text { P.U }
$$

3. Impedansi Motor 2

$\mathrm{X}^{\prime \prime}=20 \%$

$Z$ baru per - unit $=0,2\left(\frac{0,4}{10,5}\right)^{2} *\left(\frac{7500}{1061,628}\right)$

$Z$ baru per - unit $=0,2 * 0,0381^{2} * 7,07$

$Z$ baru per - unit $=0,0021$ P.U

4. Impedansi Transformator 1 $Z=3 \%$

$Z$ baru per - unit $=0,03\left(\frac{0,4}{10,5}\right)^{2} *\left(\frac{7500}{1600}\right)$

$$
Z \text { baru per }- \text { unit }=0,0002 \text { P.U }
$$

5. Impedansi Transformator 2, 3 dan 4 $Z=4,5 \%$

$Z$ baru per - unit $=0,03\left(\frac{0,4}{10,5}\right)^{2} *\left(\frac{7500}{2000}\right)$

$Z$ baru per - unit $=0,0002$ P.U

6. Impedansi Transformator 5

$Z=4,5 \%$

$Z$ baru per - unit $=0,03\left(\frac{0,4}{10,5}\right)^{2} *\left(\frac{7500}{800}\right)$

$Z$ baru per - unit $=0,0004$ P.U

7. Impedansi Penghantar $\left(Z_{12}\right)$

$Z 1=0,1344+j 0,3158 \Omega / \mathrm{km}$

Dengan jarak penghantar $Z_{12}=100 \mathrm{~m}$

Maka nilai Z1 dengan ukuran panjang $100 \mathrm{~m}$ yaitu sebesar 
$\mathrm{Z1}(100 \mathrm{~m})=0,01344+\mathrm{j} 0,03158 \Omega=0,0343 /[66,94$

\section{$\Omega$}

Untuk memperoleh nilai impedansi per unit digunakan rumus sebagai berikut :

$\begin{array}{ll}\text { Zbaruper-unit }= & \frac{(\text { Zlama } * \text { kVA baru })}{(k V \text { baru })^{2} * 1000} \\ \text { Zbaruper-unit }= & \frac{(0,0343 / 666,94 * 7500)}{(10,5)^{2} * 1000}\end{array}$

$Z$ baru per - unit $=0,00233 / \_66,94$

$Z$ baru per - unit $=-0,0024 P$. U.

8. Impedansi Penghantar $\left(\mathrm{Z}_{45}, \mathrm{Z}_{24}, \mathrm{Z}_{25}, \mathrm{Z}_{16}\right.$, dan $\left.\mathrm{Z}_{56}\right)$ $\mathrm{Z} 1=0,2688+\mathrm{j} 0,3376 \Omega / \mathrm{km}$

Dengan jarak penghantar $\mathrm{Z}_{45}$ dan $\mathrm{Z}_{56}=100 \mathrm{~m}$

Maka nilai Z1 dengan ukuran panjang $100 \mathrm{~m}$ yaitu sebesar

$\mathrm{Z} 1(100 \mathrm{~m})=0,02688+\mathrm{j} 0,03376 \Omega=0,04315 / \_51,47$

$\Omega$

Untuk memperoleh nilai impedansi per unit digunakan rumus sebagai berikut :

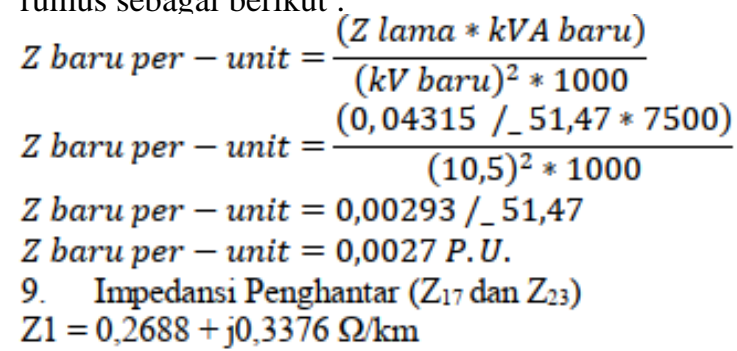

Dengan jarak penghantar $Z_{17}$ dan $Z_{23}=300 \mathrm{~m}$

Maka nilai $\mathrm{Z1}$ dengan ukuran panjang $300 \mathrm{~m}$ yaitu sebesar

$\mathrm{Z1}(300 \mathrm{~m})=0,0806+\mathrm{j} 0,10128 \Omega=0,1294$ _ 51,47

$\Omega$

Untuk memperoleh nilai impedansi per unit digunakan rumus sebagai berikut :

$$
\begin{aligned}
& Z \text { baru per }- \text { unit }=\frac{(Z \text { lama } * k V A \text { baru })}{(\text { kV baru })^{2} * 1000} \\
& Z \text { baru per }- \text { unit }=\frac{\left(0,1294 / \_51,47 * 7500\right)}{(10,5)^{2} * 1000} \\
& Z \text { baru per }- \text { unit }=0,0087 /{ }_{-51,47} \\
& Z \text { baru per }- \text { unit }=0.008 \text { P.U. }
\end{aligned}
$$

Berdasarkan hasil perhitungan diatas, maka nilai-nilai empedansi per satuan unit diperlihatkan pada gambar 7.

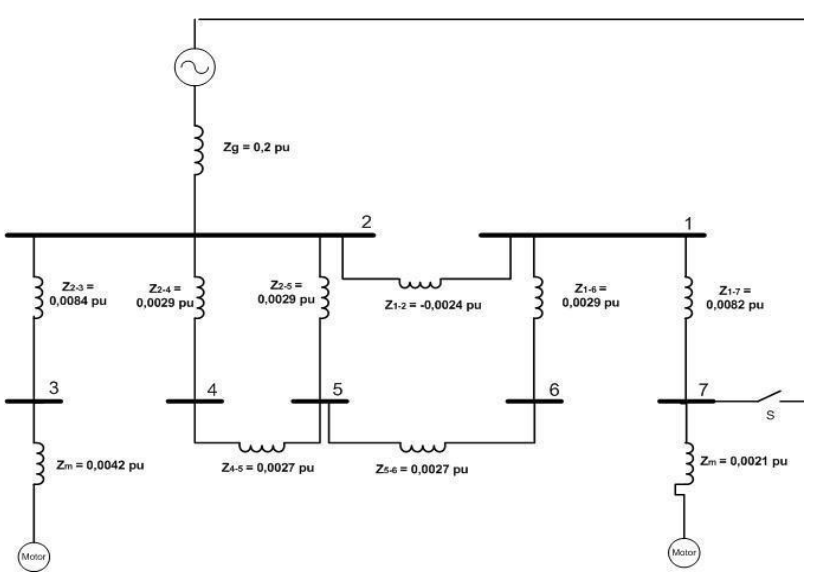

\section{Gambar 7 Rangkaian Ekivalen Admitansi}

Setelah menentukan nilai impedansi setiap elemen rangkaian, selanjutnya membuat matriks sesuai jumlah bus pada rangkaian. Krena terdapat 7 bus dalam rangkaian maka matriks yang dibuat yaitu matriks $7 \times 7$. Sehingga matriks $7 \times 7$ yang dihasilkan dapat dilihat dibawah ini :

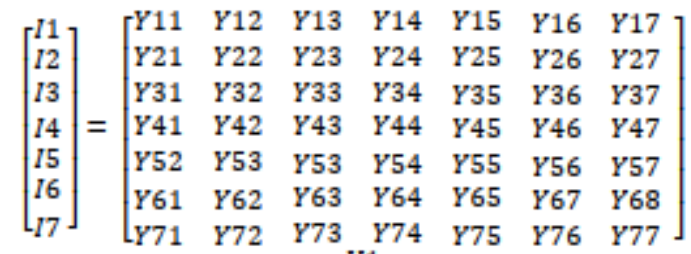

$$
\left[\begin{array}{l}
V 1 \\
V 2 \\
V 3 \\
V 4 \\
V 5 \\
V 6 \\
V 7
\end{array}\right]
$$

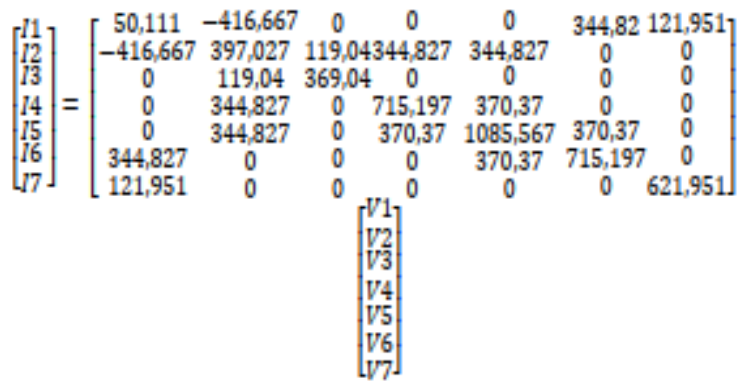

Dengan memperoleh nilai admintansi tiap bus, selanjutnya matriks $\mathrm{Y}$ harus di inverskan untuk dapat menentukan nilai I7 pada bus 7. Hasil dari invers matriks $Y$ diperlihatkan dibawah ini :

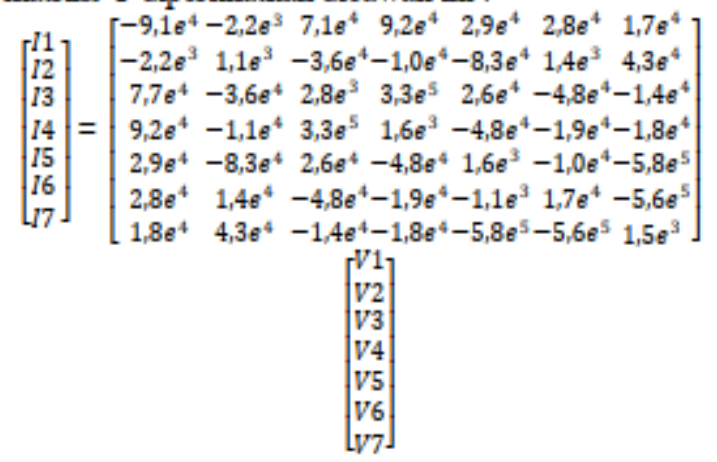

Berdasarkan hasil invers matriks tersebut, invers diatas disebut sebagai nilai Zrel yang akan digunakan untuk menghitung nilai arus hubung singkat 3 fasa. Biasanya jala-jala yang mengalami gangguan dimisalkan tidak berbeban sebelum gangguan. Dengan menggunakan prinsip superposisi maka arus yang sebelum gangguan, dan semua tegangan di seluruh jalajala adalah sama dengan $V_{f}$. Karena titik gangguan berada di tegangan $0,4 \mathrm{kV}$, maka untuk menentukan nilan Vf dengan menggunakan rumus :

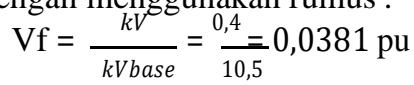


Dengan menggunakan nilai Vf diatas, maka nilai arus gangguan hubung singkat pada bus 7 adalah

$$
\begin{gathered}
I_{\mathrm{f}}=\frac{0,0381}{0,0015}=25,4 \mathrm{pu} \\
\mathrm{I}_{\mathrm{f}}=25,4 * \frac{7500}{\sqrt{ } 3 * 10,5}=10478 \mathrm{~A}
\end{gathered}
$$

Adapun perbandingan hasil perhitungan dan simulasi Digsilent PowerFactor 15.1 ditampilkan pada tabel 1 dan 2 :

Tabel 1 perbandingan nilai arus hunug singkat

\begin{tabular}{ccc}
\hline $\begin{array}{c}\text { Nomor } \\
\text { Bus }\end{array}$ & $\begin{array}{c}\text { Hasil Pehitungan } \\
(\mathbf{A})\end{array}$ & $\begin{array}{c}\text { Hasil } \\
\text { Simulasi } \\
(\mathbf{A})\end{array}$ \\
\hline 1 & 2061,965 & 2291 \\
\hline 2 & 2087 & 2266 \\
\hline 3 & 4643,398 & 4996 \\
\hline 4 & 7730,868 & 7741 \\
\hline 5 & 7735 & 7285 \\
\hline 6 & 7329 & 7737 \\
\hline
\end{tabular}

Tabel 2 Arus maksimum dan minimum Pt. Makassar Tene

\begin{tabular}{cccccccc}
\hline $\begin{array}{c}\text { Gangguan } \\
\text { Pada Rel }\end{array}$ & 1 & 2 & 3 & 4 & 5 & 6 & 7 \\
\hline $\begin{array}{c}\text { Arus } \\
\text { gangguan } \\
\text { minumum } \\
(\mathbf{A})\end{array}$ & 20 & 20 & 14 & 64 & 61 & 60 & 14 \\
\hline $\begin{array}{c}\text { Arus } \\
\text { gangguan }\end{array}$ & 22 & 22 & 49 & 77 & 72 & 77 & 95 \\
maksimum & 91 & 66 & 96 & 41 & 85 & 37 & 82
\end{tabular}

(A)

Untuk menghitung waktu kerja pada sisi OCR3, maka terlebih dahulu menghitung nilai arus setting dengan cara:

$$
\begin{gathered}
\text { Iset }=0,8 * \operatorname{In} A \\
\text { Iset }=0,67 * 1200 A \\
\text { Iset }=809,24 A
\end{gathered}
$$

Setelah memperoleh besar nilai arus setting, maka setting TMS pada OCR2 dapat pula ditentukan. Dengan mengambil nilai awal setting TMS sebesar 1, maka waktu operasi yang akan diperoleh OCR2 ketika terjadi kegagalan kerja pada OCR3 yaitu selama :

$$
\begin{gathered}
\text { T Operasi }=\frac{0,14 * \text { TMS }}{\left(\frac{\text { If }}{\text { Iset }}\right)^{0,02}-1} \text { detik } \\
\text { T Operasi }=\frac{0,14 * 1}{\left(\frac{1156,06}{809,24}\right)^{0,02}-1} \text { detik } \\
\text { T Operasi }=11,73 \text { detik }
\end{gathered}
$$

Berdasarkan perhitungan diatas, maka waktu operasi yang akan diperoleh OCR2 ketika terjadi kegagalan kerja pada OCR3 yaitu selama 11,73 detik setelah terjadinya gangguan. Waktu ini dianggap terlalu lama dalam melakukan kerja proteksi sebagai backup protection setelah terjadi gangguan.
Kalau hal tersebut terjadi, maka dikhawatirkan sistem backup protection akan bekerja lebih awal dibandingkan sistem main protection dalam menanggapi masalah. Oleh karena itu nilai setting TMS diubah sebesar 0,03 untuk mengatasi kemungkinan tersebut. Sehingga diperoleh waktu kerja backup protection sebesar

$$
\begin{gathered}
\text { T Operasi }=\frac{0,14 * \text { TMS }}{\left(\frac{\text { If }}{\text { Iset }}\right)^{0,02}-1} \text { detik } \\
\text { T Operasi }=\frac{0,14 * 0,03}{\left(\frac{1156,06}{809,24}\right)^{0,02}-1} \text { detik } \\
\text { T Operasi }=0,35 \text { detik }
\end{gathered}
$$

Berdasarkan perhitungan diatas, maka waktu perasi yang akan diperoleh OCR sebagai backup otection dianggap ideal dan mampu bekerja sesuai ordinasi yang diinginkan.

Selain arus setting, perlu juga diperhatikan juga efek dari Inrush current. Inrush current yaitu arus yang mengalir pada sebuah transformator ketika dialiri sumber tegangan dalam keadaan tanpa beban (no load). Inrush current sendiri dapat bernilai 3 hingga 60 kali nilai arus nominal sehingga dapat mengaktifkan sistem proteksi yang terpasang walaupun kondisi tersebuut tidak diingikan.

Dalam penelitian kali ini, Inrush current ditentukan sebesar 4 kali arus nominal sehingga nilai Inrush current sebesar :

$$
\text { Inrush current }=\operatorname{In} * 4 \mathrm{~A}
$$$$
\text { Inrush current }=1156,06 * 4 \mathrm{~A}
$$$$
\text { Inrush current }=4624,27 \mathrm{~A}
$$

Dengan mengambil nilai setting TMS sebesar 0,03 maka waktu operasi yang akan diperoleh pada sisi backup protection yaitu selama :

$$
\begin{gathered}
\text { T Operasi }=\frac{0,14 * \text { TMS }}{\left(\frac{\text { Inrush }}{\text { Iset }}\right)^{0,02}-1} \text { detik } \\
\text { T Operasi }=\frac{0,14 * 0,03}{\left(\frac{4624,27}{809,24}\right)^{0,02}-1} \text { detik } \\
\text { T Operasi }=0,12 \text { detik }
\end{gathered}
$$

Berdasarkan hasil perhitungan maka kurva koordinasi overcurrent relay dapat dilihat pada gambar 8 


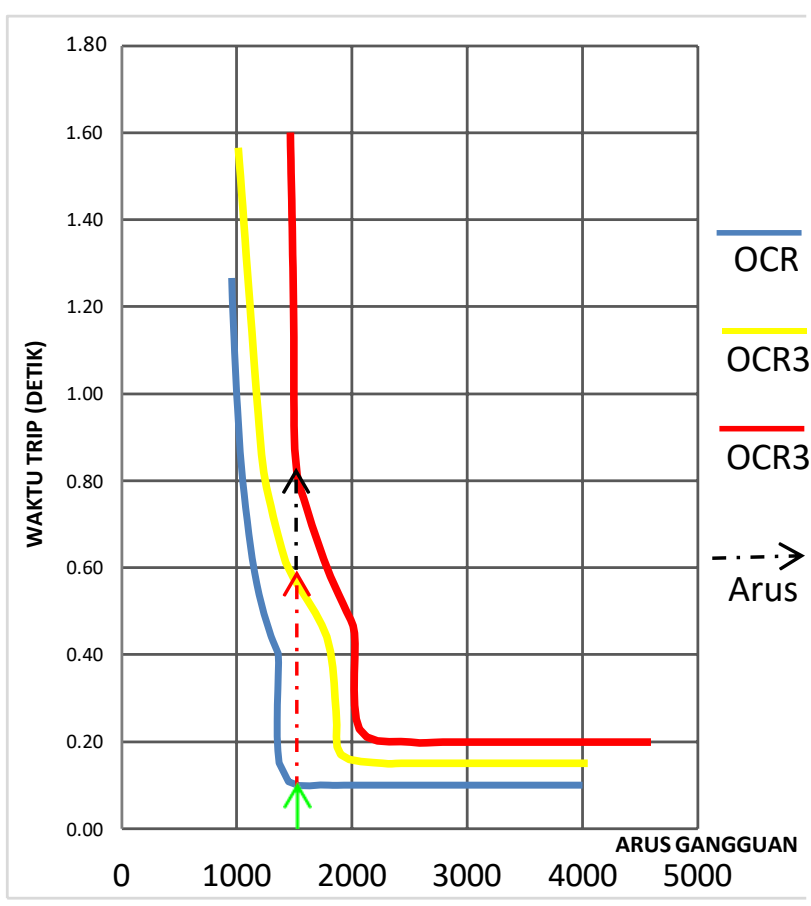

Gambar 8 Kurva Koordinasi Overcurrent Relay di Titik Gangguan

\section{KESIMPULAN}

Berdasarkan analisis yang telah dilakukan pada bab IV, maka didapatkan kesimpulan pada penelitian di PT. Makassar Tene kali ini yaitu :

1. Hasil perhitungan arus hubung singkat 3 fasa diperoleh nilai pada bus 1 sebesar $2,06 \mathrm{kA}$, bus 2 sebesar 2,08 kA, bus 3 sebesar 4,6 kA, bus 4 sebesar 7,7 kA, bus 5 sebesar 7,7 kA, bus 6 sebesar 7,3 kA dan bus 7 sebesar 10,5 kA.

2. Hasil simulasi Digsilent PowerFactor arus hubung singkat 3 fasa diperoleh nilai pada bus 1 sebesar 2,3 $\mathrm{kA}$, bus 2 sebesar 2,3 kA, bus 3 sebesar 4,9 kA, bus 4 sebesar 7,7 kA, bus 5 sebesar 7,3 kA, bus 6 sebesar 7,7 kA dan bus 7 sebesar 9,6 kA.

3. Setting overcurrent relay yaitu OCR1 sebesar $53 \mathrm{~A}$, OCR2 sebesar 30,82 A, OCR3 sebesar 809,24 A, OCR6 sebesar 44,04 A dan OCR7 sebesar 924,85 A

\section{UCAPAN TERIMA KASIH}

Ucapan terima kasih penulis sampaikan kepada semua pihak yang telah ikut membantu kelancaran penulisan jurnal ini khususnya kepada Bapak/Ibu : (1) Prof. Ir. Muhammad Anshar, M.Si., Ph.D.; (2) Dr. Ir. Hafsah Nirwana, S.T., M.T. ; (3) Sofyan, S.T., M.T. ; (4)Sarma Thaha, S.T., M.T. ; (5) Ahmad Gaffar S.T., M.T. ; (6) Orang tua kami tercinta; (7) Teman-teman dan pihak-pihak lain yang tidak bisa penulis sebutkan satu persatu dalam jurnal ini.

\section{REFERENSI}

[1]Edvard. (2013, 01 14). Retrieved 11 28, 2018, From Electrical Engineering Portal: Https://ElectricalEngineering-Portal.Com

[2]Linsley, T. (2004). Instalasi Listrik Tingkat Lanjut (Vol. 3 (Tiga)). Jakarta: Erlangga.

[3]Marsudi, D. (2005). Pembangkitan Energi Listrik. Jakarta: Erlangga.

[4] Muslim, S. (2008). Teknik Pembangkit Tenaga Listrik. Jakarta: Kemendikbud.

[5] Setyawan, A. (2008). Analisa Sistem Proteksi Generator Pada Pusat Pembangkit Listrik Tenaga Air Wonogiri. Surakarta: Universitas Muhammadiyah Surakarta.

[6] Taiyeb, S. (2006). Studi Proteksi Gangguan Sistem Terhadap Generator Di Sektor Tello. Makassar: Politeknik Negeri Ujung Pandang.

[7] Warda. (2008). Studi Sistem Proteksi Pada Belitan Generator Pltgu Pt. Energi Sengkang. Makassar: Politeknik Negeri Ujung Pandang.

[8] William D, J. S. (1996). Analisa Sistem Tenaga Listrik. (I. K. Idris, Ed.) Jakarta: Erlangga. 